\title{
EDITORIAL
}

\section{Management of chronic obstructive pulmonary disease: are we going anywhere?}

\author{
S. Rennard ${ }^{+}$, M. Carrera*, A.G.N. Agustí*
}

The gold standard for a clinical intervention is the randomized controlled trial [1]. In contrast, evaluating a clinical outcome based on historical comparisons is fraught with numerous problems due to changes in a variety of factors including: a) diagnostic criteria and techniques; b) management of comorbid conditions; c) disease associated behaviours; and d) research methods, to name a few. As a result, conclusions based on historical comparisons are generally regarded as highly suspect. It is, nevertheless, important to view historical trends carefully as important lessons may be gleaned from such reviews.

In this context, review of the survival of patients with hypoxaemic chronic obstructive pulmonary disease (COPD) in a historical context is instructive. The now classic, Medical Research Council (MRC) oxygen trial conducted in the 1970's provided clear evidence for the benefit of oxygen therapy in hypoxaemic patients with COPD who showed evidence of right sided heart failure [2]. The Nocturnal Oxygen Therapy Trial conducted at about the same time supported the notion that continuous oxygen was superior to nocturnal oxygen supplementation in hypoxaemic COPD patients who were not selected for evidence of right-sided heart failure [3]. Based on these trials, it would, at the present time, be regarded as unethical to perform a survival study in hypoxaemic COPD patients managed without oxygen support. Several subsequent studies, however, have been conducted which provide evidence for the survival of hypoxaemic COPD patients managed with oxygen support [4-6]. Interestingly, these studies seem to show a progressive improvement in survival with time (fig. 1).

As noted, there are several nonexclusive reasons, which could account for this trend. Patient selection may be an important one. Specifically, provision of oxygen therapy to individuals who were not as ill as those originally studied would result in an apparent improved survival due entirely to subject selection. These changes in subject selection may have been due to an aggressive change in diagnostic practice, for example implementation of percutaneous oximetry and increased case ascertainment. However, the raw comparison of several potential confounding variables determined at entry in the study (table 1) suggests that this

\footnotetext{
${ }^{+}$The University of Nebraska Medical Centre, Omaha, NE, USA *Hospital Universitario Son Dureta, Palma de Mallorca, Spain.

Correspondence: A.G.N. Agustí, Servei Pneumologia, Hospital Universitario Son Dureta, Andrea Doria 55, 07014 Palma de Mallorca, Spain. Fax: 34971175228
}

was not the case. Alternatively, implementation of other therapies, for example aggressive use of bronchodilator treatment, pulmonary rehabilitation, etc. may account for improved survival. Likewise, survival may have changed with altered behaviour in the patient population, for example decreased cigarette smoking. Finally, management of comorbid conditions, e.g. cardiac disease may have contributed to improved survival. It is, nevertheless, of interest that COPD mortality appears to have improved over the past few decades (fig. 1) while survival for patients with lung cancer has changed relatively little despite their similar demographics [7].

While there are many questions raised by the trends in COPD mortality as discussed, there are also several lessons to be learnt. First, much of the thinking about COPD, particularly regarding its natural history, is based on historical studies. Probably, the natural history of the disease, at least with regard to survival, now differs from these historical studies. As advances are continued to be made in the understanding and management of COPD, it is essential not to be bound by the out-moded conclusions of older studies. Perhaps more importantly, credit needs to be taken for the advances achieved over the past few decades. The situation certainly appears to look better for the hypoxaemic COPD patient now than it did in the 1970s. As many clinicians will recognize, patients with COPD and overt cor pulmonale have almost disappeared from the

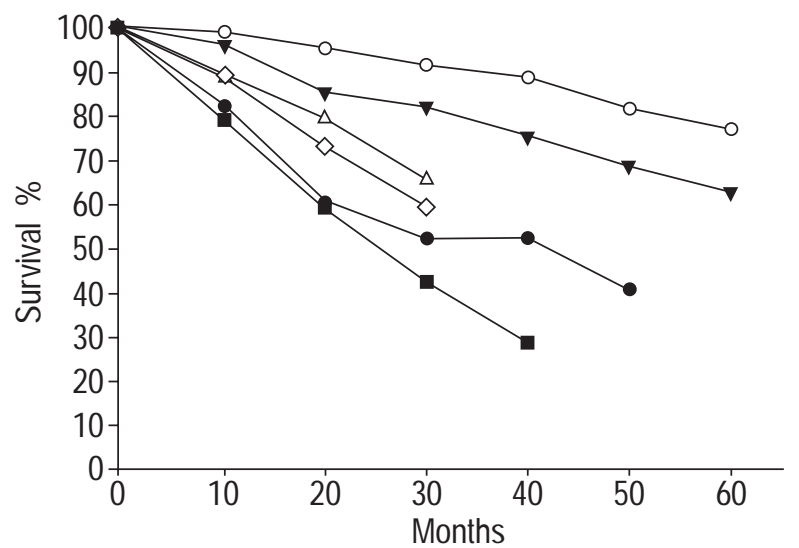

Fig. 1. - Survival of patients with chronic obstructive pulmonary disease and chronic respiratory failure treated with long-term oxygen therapy reported by several studies in the literature [2-6]. Note a trend towards increased survival in more recent studies. $\bigcirc$ : CARRERA et al. [6] (with $\mathrm{O}_{2}$ ) 1999; $\mathbf{\nabla}$ : CoOper et al. [4] (with $\mathrm{O}_{2}$ ) 1987; $\triangle$ : Nocturnal Oxygen Therapy Trial group [3] $\left(\right.$ with $\left.\mathrm{O}_{2}\right) 1980 ; \diamond:$ STRÖM [5] (with $\mathrm{O}_{2}$ ) 1983; : Medical Research Council [2] (with $\mathrm{O}_{2}$ ) 1981; Medical Research Council [2] (without $\mathrm{O}_{2}$ ) 1981. 
Table 1. - Comparison of potential confounding variables at entry in the studies included in figure 1

\begin{tabular}{lrcccccc}
\hline Reference & $\mathrm{N}$ & $\begin{array}{c}\text { Age } \\
\text { yrs }\end{array}$ & $\begin{array}{c}\text { Sex } \\
\% \text { male }\end{array}$ & $\begin{array}{c}\text { Follow-up } \\
\text { yrs }\end{array}$ & FEV1 & $\begin{array}{c}P_{\mathrm{a}, \mathrm{O}_{2}} \\
\mathrm{mmHg}\end{array}$ & $\begin{array}{c}P_{\mathrm{a}, \mathrm{CO}_{2}} \\
\mathrm{mmHg}\end{array}$ \\
\hline MRC [2] & 87 & 58 & 76 & 5 & $700 \mathrm{~mL}$ & 50 & 54 \\
NOTT [3] & 203 & 65 & 79 & 3 & $29 \% \mathrm{ref}$ & 51 & 43 \\
COOPER [4] & 72 & 60 & 74 & 12 & $780 \mathrm{~mL}$ & 43 & 48 \\
STRÖM [5] & 403 & 68 & 50 & 2.5 & $700 \mathrm{~mL}$ & 50 & 49 \\
CARRERA [6] & 257 & 70 & 79 & 3 & $840 \mathrm{~mL}$ & 53 & 48 \\
\hline
\end{tabular}

FEV1: forced expiratory volume in one second; $\mathrm{Pa}, \mathrm{O}_{2}$ : oxygen tension in arterial blood; $\mathrm{Pa}_{\mathrm{a}} \mathrm{CO}_{2}$ : carbon dioxide tension in arterial blood. MRC: Medical Research Council; NOTT: Nocturnal Oxygen Therapy Trial.

hospitalization wards now. Whilst it may be hard to explain which portions of the current management contributes to this improved outlook and by what measure credit should be taken for these advances. Too many physicians and patients are complacent about the diagnosis and management of COPD based on the assumption that relatively little is effective. This prejudice may be complicated by the fact that many patients with COPD suffer from a selfinflicted chronic disease. It is particularly paradoxical that the approach to COPD is relatively passive when the historical record suggests that gains have been made in COPD management.

Without doubt, the current management of patients with COPD leaves much to be desired. Currently ongoing investigations hold much promise for improved therapy in the near and not so near future $[8,9]$. These therapies, however, are most likely to be developed on a changing natural history of COPD. It is positive that these therapies will continue this historical trend and that, over the next few decades, the management of COPD will continue to improve.

\section{References}

1. Ioanndis JPA, Cappelleri JC, Lau J. Meta-analyses and large randomized controlled trials. $N$ Engl J Med 1998; 338: 59-62.
2. Report of the Medical Research Council Working Party. Long term domiciliary oxygen therapy in chronic hypoxic cor pulmonale complicating chronic bronchitis and emphysema. Lancet 1981; i: 681-685.

3. Nocturnal Oxygen Therapy Trial Group. Continuos or noctural oxygen therapy in hypoxemic chronic obstructive lung disease. A clinical trial. Ann Intern Med 1980; 93: 391-398.

4. Cooper CB, Waterhouse JC, Howard P. Twelve year clinical study of patients with hypoxic cor pulmonale given long term domiciliary oxygen therapy. Thorax 1987; 42: 105-110.

5. Ström K. Survival of patients with chronic obstructive pulmonary disease receiving long-term domiciliary oxygen therapy. Am Rev Respir Dis 1993; 147: 585-591.

6. Carrera M, Sauleda J, Bauzá F, et al. Resultados de la actuación de una unidad de control de la oxigenoterapia domiciliaria. Arch Bronconeumol 1999; 35: 33-38.

7. Kanters SDJM, Lammers J-WJ, Voest EE. Molecular and biological factors in the prognosis of non-small cell lung cancer. Eur Respir J 1995; 8: 1389-1397.

8. Barnes PJ. New therapies for chronic obstructive pulmonary disease. Thorax 1998; 53: 137-147.

9. Ingenito EP, Reilly JJ, Lutchen KR, et al. Bronchoscopic volume reduction: an effective and safe alternative to surgical therapy. Am J Respir Crit Care Med 2000; 161: A750 (Abstract). 